\title{
Herbicides for Control of Wild Garlic in Turfgrass
}

\author{
Zachary D. Small ${ }^{1}$, James D. McCurdy ${ }^{1}$, Erick D. Begitschke ${ }^{1}$, \\ and Michael P. Richard ${ }^{1}$
}

Additional InDEX wORDs. Allium vineale, ALS inhibitors, synthetic auxins, visual injury, weed management

Summary. Wild garlic (Allium vineale) is an annual winter weed in managed turfgrass. Its dark green, upright stems are easily distinguishable among low-lying, dormant warm-season grasses. Experiments were conducted to determine the effectiveness of synthetic auxin and acetolactate synthase (ALS) inhibiting herbicides for post-emergence control of wild garlic. Trials were conducted in 2016 and 2017. Throughout both trial years, synthetic auxin herbicides exhibited visual control quicker than ALS inhibitors at the initial assessment date $20 \mathrm{~d}$ after application (DAA). Conversely, at the final assessment date 49 DAA, ALS inhibitors were the only treatments that controlled wild garlic by more than $85 \%$. In 2016 , plots treated with $2,4-D+$ dicamba + mecoprop at $4 \mathrm{pt} /$ acre exhibited $88 \%$ visual control when assessed 20 DAA, but this level had decreased to $51 \%$ by 49 DAA. Similarly, visual control in plots treated with 2,4-D + mecoprop + dicamba + carfentrazone-ethyl at $4 \mathrm{pt} /$ acre decreased from $59 \%$ to $56 \%$ and $82 \%$ to $18 \%$ between assessment dates in 2016 and 2017, respectively. Metsulfuron-methyl at $0.5 \mathrm{fl} \mathrm{oz} /$ acre controlled wild garlic $94 \%$ and $91 \%$ at the 49 DAA assessment date, whereas sulfentrazone + metsulfuron-methyl at $0.41 \mathrm{lb} /$ acre controlled wild garlic $93 \%$ and $95 \%$ at the same assessment dates in 2016 and 2017, respectively. Future research should consider tank mixes of auxin-mimicking and ALS-inhibiting herbicides as potential routes for quick burndown and season-long control.

W ild garlic, a plant native to Europe, is a troublesome turfgrass weed throughout the southeastern United States. A member of the lily family (Liliaceae), the dark green color of this plant stands out among warm-season turfgrass species during winter dormancy periods. Wild garlic is a monocot that is morphologically characterized as an erect perennial herb that can grow up to $90 \mathrm{~cm}$ in height (Bryson and DeFelice, 2009). Shoots are hollow and rounded and release a distinct alliaceous, or "garlicky," odor upon crushing or cutting.

Despite its prominence as a weed in maintained turfgrass, published research pertaining to wild garlic control has been somewhat limited.

Received for publication 16 Apr. 2019. Accepted for publication 5 Aug. 2019

Published online 2 October 2019.

${ }^{1}$ Department of Plant and Soil Science-Mississippi State University, 32 Creelman Street, Mississippi State, MS 39759

Current address (E.D.B.): SePRO Corp., 16013 Watson Seed Farm Rd., Whitakers, NC 27891

Z.D.S. is the corresponding author. E-mail: zds51@ msstate.edu.

This is an open access article distributed under the CC BY-NC-ND license (https://creativecommons.org/ licenses/by-nc-nd/4.0/).

https://doi.org/10.21273/HORTTECH04379-19
Synthetic auxin chemistries, including 2,4-D, have been used to control wild garlic (Davis et al., 1962). Auxins are not always safe to sensitive turfgrass species, particularly st. augustinegrass (Stenotaphrum secundatum) and centipedegrass (Eremochloa ophiuroides) (Kelly and Coats, 2000; Ni et al., 2006).

Nonselective herbicides have also proven useful for control of wild garlic. Glyphosate either equaled or surpassed control achieved by 2,4-D in studies by Hardcastle (1976) and Troutman et al. (1981). However, glyphosate applications are limited to warm-season species, such as bermudagrass (Cynodon dactlyon) and zoysiagrass (Zoysia japonica), during winter dormancy. Peters and McKelvey (1982) found that spring applications of paraquat in kentucky bluegrass (Poa pretensis) sod at a rate of $0.56 \mathrm{~kg} \cdot \mathrm{ha}^{-1}$ consistently controlled wild garlic; however, paraquat is not labeled for use in turfgrass. The acetolactate synthase-inhibiting herbicides, such as metsulfuron (Leys and Slife, 1987), chlorsulfuron (Ferrell et al., 2004; Leys and Slife, 1982, 1986; Patton et al., 2008), and imazethapyr (Ferguson et al., 1992), provide acceptable visual control of wild garlic ranging from to $85 \%$ to 95\%. Likewise, thifensulfuron controlled wild garlic $>90 \%$ in soft red winter wheat (Triticum aestivum) and reduced the viability of bulbs produced (Gast et al., 1990).

Prior literature on this subject largely ignores common applications in maintained turfgrass scenarios. Our objective for this study was to further evaluate commonly applied turfgrass herbicides for wild garlic efficacy.

\section{Materials and methods}

A research study, designed as a randomized complete block with four replications, was conducted near Starkville, MS, at the H.H. Leveck Animal Research Center during Winter 2016 and at the Rodney R. Foil Plant and Soil Science Research Center located near Starkville, MS. during Winter 2017. Treatments (Table 1) included nine common postemergence herbicides and a nontreated check. All were applied with a handheld, carbon dioxide $\left(\mathrm{CO}_{2}\right)$-pressurized backpack sprayer in a water carrier volume of $20 \mathrm{gal} / \mathrm{acre}$. Experimental units were $5 \times 10 \mathrm{ft}$. Herbicide applications occurred on $26 \mathrm{Feb}$. 2016 and 13 Jan. 2017 and were made when possible, based on rainfall and wild garlic growth. All treatments included $0.25 \% \mathrm{v} / \mathrm{v}$ nonionic surfactant (Preference; WinField Solutions, St. Paul, MN). Nonionic surfactant was included to increase herbicide

\begin{tabular}{llll}
\hline $\begin{array}{l}\text { Units } \\
\begin{array}{l}\text { To convert U.S. to SI, } \\
\text { multiply by }\end{array}\end{array}$ & U.S. unit & SI unit & $\begin{array}{l}\text { To convert SI to U.S., } \\
\text { multiply by }\end{array}$ \\
\hline 73.0778 & $\mathrm{fl} \mathrm{oz} / \mathrm{acre}$ & $\mathrm{mL} \cdot \mathrm{ha}^{-1}$ & 0.0137 \\
0.3048 & $\mathrm{ft}$ & $\mathrm{m}$ & 3.2808 \\
9.3540 & $\mathrm{gal} / \mathrm{acre}$ & $\mathrm{L} \cdot \mathrm{ha}^{-1}$ & 0.1069 \\
1.1209 & $\mathrm{lb} / \mathrm{acre}$ & $\mathrm{kg} \cdot \mathrm{ha}^{-1}$ & 0.8922 \\
0.1198 & $\mathrm{lb} / \mathrm{gal}$ & $\mathrm{kg} \cdot \mathrm{L}^{-1}$ & 8.3454 \\
70.0532 & $\mathrm{oz} / \mathrm{acre}$ & $\mathrm{g} \cdot \mathrm{ha}^{-1}$ & 0.0143 \\
1.1692 & $\mathrm{pt} / \mathrm{acre}$ & $\mathrm{L} \cdot \mathrm{ha}^{-1}$ & 0.8553
\end{tabular}




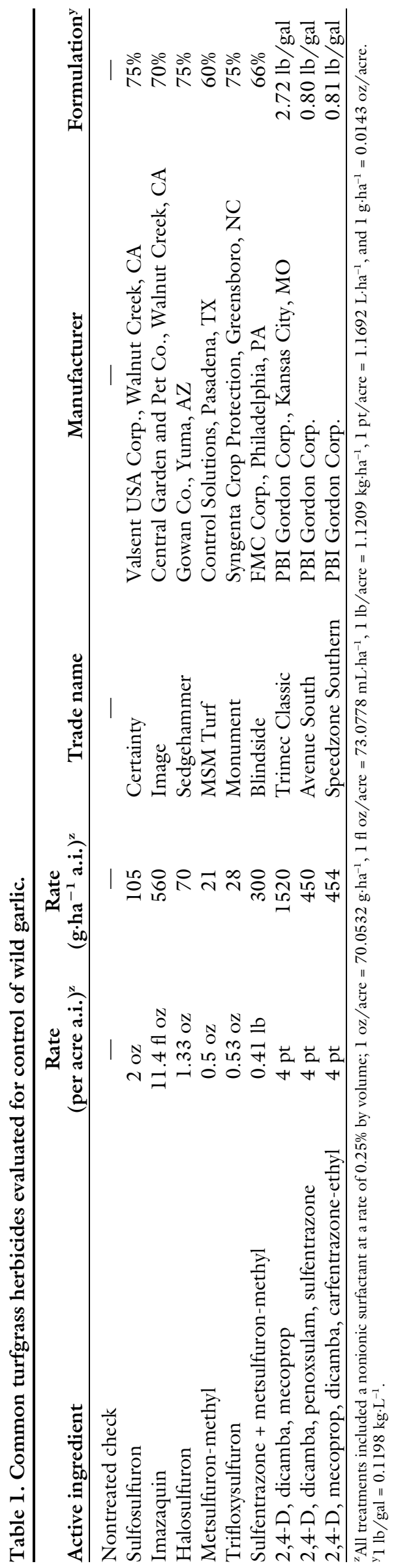

contact on the waxy leaf structure of wild garlic plants. Visual injury was assessed on a $0 \%$ to $100 \%$ scale, with $0 \%$ representing no control and $100 \%$ representing complete weed extermination, 20 and 49 DAA. Data were subject to analysis of variance $(\alpha=0.05)$ using SAS Procedure GLIMMIX mixed model analysis (SAS version 9.4; SAS Institute, Cary, $\mathrm{NC}$ ). Basic model assumptions were confirmed. A treatment-by-year interaction was significant for both assessment intervals; therefore, data are presented by year. Means were separated using Fisher's protected least significant difference test $(\alpha=0.05)$.

\section{Results}

When sites were visually assessed 20 DAA in 2016, all herbicides controlled wild garlic $\geq 50 \%$ relative to the nontreated check, suggesting all herbicides included in this study had quick burndown control of wild garlic (Table 2). All treatments controlled wild garlic better than the nontreated check when assessed 49 DAA. Sulfentrazone + metsulfuron-methyl (Blindside; FMC Corp., Philadelphia, PA) $(95 \%)$ and metsulfuron-methyl (MSM Turf; Control Solutions, Inc., Pasadena, TX) (94\%) controlled wild garlic $>90 \%$. Sulfosulfuron (Certainty; Valent USA Corp., Walnut Creek, CA), imazaquin (Image; Central Garden and Pet Co., Walnut Creek, CA), and trifloxysulfuron (Monument; Syngenta Crop Protection, Greensboro, NC) were not statistically different from products containing synthetic auxins, 2,4-D + dicamba + mecoprop (Trimec Classic; PBI Gordon Corp., Kansas City, $\mathrm{MO})$, and 2,4-D + mecoprop + dicamba + carfentrazone (Speedzone Southern, PBI Gordon Corp.) exhibited a decrease in visual control between the 20 and 49 DAA rating dates during 2016.

Visual control of wild garlic was much slower to manifest when this trial was repeated in 2017 (Table 2). All treatments with ALS-inhibiting active ingredients failed to control wild garlic greater than the nontreated check when assessed 20 DAA. Only the auxin-mimicking herbicides 2,4-D + dicamba + mecoprop, $2,4-\mathrm{D}+$ dicamba + penoxsulam + sulfentrazone, and 2,4-D + mecoprop + dicamba + carfentrazone-ethyl controlled wild garlic greater than the 
Table 2. Effect of herbicide treatments on visual control of wild garlic. Percent visual control rated 20 and $49 \mathrm{~d}$ after application (DAA) in 2016 and 2017.

\begin{tabular}{|c|c|c|c|c|}
\hline \multirow[b]{3}{*}{ Treatment } & \multicolumn{2}{|c|}{2016} & \multicolumn{2}{|c|}{2017} \\
\hline & $20 \mathrm{DAA}$ & $49 \mathrm{DAA}$ & $20 \mathrm{DAA}$ & $49 \mathrm{DAA}$ \\
\hline & \multicolumn{4}{|c|}{ Control $(\%)$} \\
\hline Sulfosulfuron & $68 \mathrm{a}$ & $86 \mathrm{ab}$ & $13 \mathrm{~d}$ & $83 \mathrm{abc}$ \\
\hline Imazaquin & $53 \mathrm{a}$ & $81 \mathrm{abcd}$ & $9 \mathrm{~d}$ & 93 a \\
\hline Halosulfuron & $50 \mathrm{a}$ & $53 \mathrm{de}$ & $33 \mathrm{~cd}$ & $66 \mathrm{abc}$ \\
\hline Sulfentrazone + metsulfuron-methyl & $65 \mathrm{a}$ & 95 a & $35 \mathrm{~cd}$ & $93 \mathrm{a}$ \\
\hline 2,4-D, dicamba, mecoprop & $75 \mathrm{a}$ & $50 \mathrm{e}$ & 88 a & $51 \mathrm{~cd}$ \\
\hline 2,4-D, dicamba, penoxsulam, sulfentrazone & $61 \mathrm{a}$ & 64 bcde & $69 \mathrm{abc}$ & $56 \mathrm{bc}$ \\
\hline 2,4-D, mecoprop, dicamba, carfentrazone-ethyl & $59 \mathrm{a}$ & 56 cde & $82 \mathrm{ab}$ & $18 \mathrm{de}$ \\
\hline
\end{tabular}

${ }^{\mathrm{z}}$ Results are comparable within year and DAA for each column only. Means followed by the same letter are not significantly different according to Fisher's least significant difference $(\alpha=0.05)$.

nontreated $(88 \%, 69 \%$, and $82 \%$, respectively) at this time. However, when assessed 49 DAA this trend reversed. $2,4-\mathrm{D}+$ dicamba + mecoprop, 2,4-D + dicamba + penoxsulam + sulfentrazone, and 2,4-D + mecoprop + dicamba + carfentrazone all exhibited a decrease in control, while sulfonylurea herbicides imazaquin, metsulfuron-methyl, trifloxysulfuron, and sulfentrazone + metsulfuronmethyl all controlled wild garlic control $>91 \%$.

All ALS-inhibiting herbicides were not statistically different from trifloxysulfuron, which provided $98 \%$ control.

\section{Discussion}

Although data could not be pooled across years, similar trends were observed in both years, pointing to a consistency in product performance overall. Combination products containing synthetic auxins, such as 2,4-D + dicamba + mecoprop, 2,4-D + dicamba + penoxsulam + sulfentrazone, and 2,4-D + mecoprop + dicamba + carfentrazone-ethyl, all achieved quick and significant burndown control of wild garlic 20 DAA. The decrease, or lack of significant increase, in control as trials progressed in both years from 20 to 49 DAA indicates that these products may not be suitable for long-term wild garlic control. Interestingly, Avenue South provided intermediate control compared with treatments containing a single mode of action.

Trial locations were unmown during the study period, which may have contributed to regrowth and recovery by auxin treated wild garlic. However, it is not atypical for similarly maintained lawns to be unmown until bermudagrass transitions out of dormancy and requires mowing.

In general, control with treatments containing ALS-inhibiting a.i. was slower to manifest in both years. At the final assessment date in both 2016 and 2017, sulfentrazone + metsulfuron-methyl and metsulfuronmethyl controlled wild garlic $>91 \%$. This suggests sulfentrazone + metsulfuron-methyl and metsulfuronmethyl alone may be best for longterm control of wild garlic among products included in this study. This study also suggests that if quick burndown control of wild garlic is desired, reliance on herbicides containing multiple synthetic auxins, such as 2,4-D + dicamba + mecoprop, $2,4-\mathrm{D}+$ dicamba + penoxsulam + sulfentrazone, or 2,4-D + mecoprop + dicamba + carfentrazone-ethyl may be required. This study strengthens the case that imazaquin (Ferrell et al., 2004; Patton et al., 2008) and metsulfuron-methyl (Leys and Slife, 1987) are reasonable control options for wild garlic in turfgrass. Emphasis of future research should be placed on reconciling the quick burndown of synthetic auxin herbicides with the season-long control from ALS-inhibitors. Studies could examine the effectiveness of repeat applications of products such as $2,4-\mathrm{D}+$ dicamba + mecoprop for season-long control of wild garlic. In addition, tank mixes containing both sulfonylurea and auxin-mimicking herbicides should be tested to explore the possibility of combining these modes of action for quick burndown as well as seasonlong control.

\section{Literature cited}

Bryson, C.T. and M.S. DeFelice. 2009. Weeds of the South. Univ. Georgia Press, Athens, GA.

Davis, F.S., E.J. Peters, D.L. Klingman, H.D. Kerr, and O.H. Fletchall. 1962. Chemical control of wild garlic. Weeds 10:281-284

Ferguson, G.P., G.E. Coats, G.B. Wilson, and D.R. Shaw. 1992. Postemergence control of wild garlic (Allium vineale) in Turfgrass. Weed Technol. 6:144-148.

Ferrell, J., T. Murphy, and C. Waltz. 2004. The sulfonylurea herbicides: Where do they fit in turfgrasses? 6 Apr. 2019. <http://caes2. caes.uga.edu/commodities/turfgrass/ georgiaturf/WeedMngt/weedcontrol/ TURFSULFONYLUREA.pdf $>$.

Gast, R.E., R.A. Liebl, and F.W. Slife. 1990. Wild garlic (Allium vineale) control with thifensulfuron and DPX-L5300. Weed Technol. 4:592-597.

Hardcastle, W.S. 1976. Chemical control of wild allium species. Agron. J. 68:144145 .

Kelly, S.T. and G.E. Coats. 2000. Virginia buttonweed (Diodia virginiana) control with pyridine herbicides. Weed Technol. 14:591-595.

Leys, A.R. and F.W. Slife. 1982. The effect of sulfonylurea herbicides on wild garlic, winter wheat, and double-cropped soybeans. Proc. North Central Weed Control Conf. 37:16.

Leys, A.R. and F.W. Slife. 1986. The response of wild garlic (Allium vineale) to 
the timing of spray applications of chlorsulfuron. Weed Sci. 34:718-723.

Leys, A.R. and F.W. Slife. 1987. Comparison of chlorsulfuron and metsulfuron for control of AIlium vineale L. Weed Res. 27:35-41.

Ni, H., G. Wehtje, R.H. Walker, J.L. Belcher, and E.K. Blythe. 2006. Turf tolerance and virginia buttonweed (Diodia virginiana) control with fluroxypyr as influenced by the synergist diflufenzopyr. Weed Technol. 20:511-519.

Patton, A.J., M.D. Richardson, D.E. Karcher, J.W. Boyd, Z.J. Reicher, J.D. Fry, J.S. McElroy, and G.C. Munshaw. 2008. A guide to establishing seeded bermudagrass in the transition zone. Appl. Turfgrass Sci., doi: 10.1094/ATS-2008-0122-01-MD.
Peters, E.J. and R.A. McKelvey. 1982. Herbicides and dates of application for control and eradication of wild garlic (Allium vineale). Weed Sci. 30:557-560.

Troutman, B., J. King, and R. Frans. 1981. Wild garlic (Allium vineale) control with glyphosate. Weed Sci. 29:717722. 